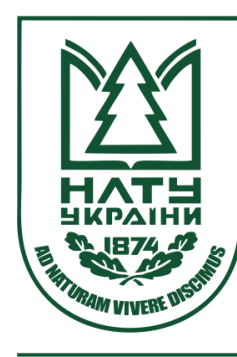

Науковий вісник НлтУ України Scientific Bulletin of UNFU

https://nv.nltu.edu.ua

https://doi.org/10.15421/40280803

$@ \bowtie$ Correspondence author

Article received 03.10.2018 p.

Article accepted 25.10.2018 p.

R. Ya. Tatarchuk

Удк 632.516:712.58(477.25)

С. Б. Ковалевський 1 Р. Я. Татарчук ${ }^{2}$

${ }^{I}$ Національний університет біоресурсів і природокористування України, м. Київ, Україна

${ }^{2}$ ВП НУБіП Украйни "Боярський коледж екології і природних ресурсів", м. Боярка, Україна

\title{
СИНАНТРОПНА РОСЛИННІСТЬ У КАМ'ЯНИСТИХ САДАХ КИЄВА
}

Визначено основну проблему догляду за кам'янистими садами - боротьба із бур'янами. Виявлено синатропну рослинність (бур'яни) кам'янистих садів Києва. Наведено перелік бур'янів, які найчастіше трапляються на дослідних ділянках. Дослідження проведено у насадженнях різного функціонального призначення (насадження загального користування, насадження обмеженого користування, насадження спеціального призначення). Проаналізовано 19 видів бур'янів, які належать до 12 родин, враховано способи їх поширення і причини стійкості в кам'янистих садах. Встановлено, що поширення бур'янів дуже виснажують грунт, ускладнюють догляд за кам'янистим садом, знижують загальну декоративність кам'янистих композицій, сприяють розвитку шкідників та хвороб. Запропоновано методи боротьби з бур'янами та низку інших агротехнічних заходів, які покращать декоративний вигляд кам'янистих садів. Виділено біологічні групи малорічних та багаторічних бур'янів. Виявлено, що за тривалістю життя в насадженнях переважають однорічні бур'яни, які належить до класу Дводольні. Проаналізовано спектр дії гербіцидів та визначено найефективніші препарати для боротьби з бур'янами. Залежно від виду препарату та інтенсивності росту бур'янів у кам'янистих садах запропоновано кратність оброблення гербіцидами. Дослідження за ростом бур'янів здійснено від ранньої весни до пізньої осені. Роботу виконано шляхом маршрутних обстежень.

Ключові слова: бур'яни; кам'янистий сад; догляд; гербіциди.

Вступ. Боротьба з бур'янами - один 3 найважливіших заходів догляду за кам'янистими садами. Достатньо припинити догляд за кам'янистими композиціями на деякий період, як серед них починає з'являтись небажана рослинність, яка швидко займає значну площу та витісняє культурні рослини. Бур'яни виносять із грунту значну кількість поживних речовин, конкурують 3 культурними рослинами за вологу, світло, а також досить часто на них розвиваються і поширюються різні шкідники і хвороби.

На ділянки кам'янистих садів бур'яни потрапляють різними способами, а саме: переносяться вітром, птахами і тваринами, потрапляють разом із грунтом під час створення даних композицій. Тому боротьбу з бур'янами потрібно здійснювати систематично, щорічно від ранньої весни до пізньої осені, і в жодному разі не можна допустити, щоб бур'яни зацвіли і дозріло їх насіння.

Процес боротьби з бур'янами охоплює два способи: механічний і хімічний. Механічний спосіб (прополювання) - трудомісткий процес, особливо на великих площах. Бур'яни видаляють за допомогою вузького совка, ножа або гостро заточеної сталевої смужки. Хімічний спосіб - використання гербіцидів (хімічних засобів для боротьби з бур'янами, шкідниками та хворобами).

Сьогодні використовують також інший спосіб боротьби з бур'янами - мульчування грунту за допомогою декоративної крихти та кори хвойних рослин, внаслідок чого помітно скорочується зростання бур'янів в кам'янистих садах. Для успішної боротьби з бур'янами в кам'янистих садах необхідно знати їх види, умови поширення, способи розмноження і причини стійкості.

Матеріали й методи дослідження. Щоб дослідити найпоширеніші бур'яни в кам'янистих садах, проаналізовано 20 експериментальних ділянок, які знаходились у насадженнях різного функціонального призначення. Для дослідних ділянок характерні різні грунтові умови, особливості рельєфу (на рівному рельєфі, на схилах, на штучному рельєфі), розміри (малі, середні, великі, крупні), особливості композиційного рішення (домінування рослинності над камінням, домінування каміння над рослинністю, домінування водойми) та наявність догляду (табл. 1).

У процесі дослідження вивчали види бур'янів, зайняту ними площу ділянки та способи боротьби з ними.

Результати дослідження. Кам'янисті сади в Києві трапляються у насадженнях різного функціонального призначення. Дослідні ділянки істотно відрізняються за площею, особливостями рельєфу, належать до різних категорій (див. табл. 1). За нашими дослідженнями, догляд за кам'янистими садами виконують нерегулярно, а інколи зовсім не здійснюють. Для покращення декоративного вигляду кам'янистих композицій та підтримання їх у належному стані, рекомендовано виконувати такі агротехнічні заходи: розпушування грунту, полив,

\section{Інформація про авторів:}

Ковалевський Сергій Борисович, д-р с.-г. наук, професор, кафедра ботаніки, дендрології та лісової селекції.

Email: s.kovalevsky@ukr.net

Татарчук Руслана Ярославівна, здобувач, кафедра ботаніки, дендрології та лісової селекції. Email: v_rusia82@ukr.net

Цитування за ДСтУ: Ковалевський С. Б., Татарчук Р. Я. Синантропна рослинність у кам'янистих садах Києва. Науковий вісник НлтУ України. 2018, т. 28, № 8. С. 19-22.

Citation APA: Kovalevskii, S. B., \& Tatarchuk, R. Ya. (2018). Sinantropic vegetation in stony gardens of Kiev. Scientific Bulletin of UNFU, 28(8), 19-22. https://doi.org/10.15421/40280803 
внесення добрив, мульчування, прополювання, укриття на зиму, обрізування дерев та кущів, видалення сухих гілок та суцвіть, боротьба з бур'янами, захист від шкідників та хвороб, догляд за насадженнями впродовж року.

Головною проблемою у догляді за кам'янистими садами є боротьба з бур'янами, дикорослими однорічниками та багаторічними рослинами, що відзначаються активним ростом, розмноженням та пристосованістю до умов середовища. Користуючись визначниками-довідниками (Barbarych et al., 1970; Veselovskyi, Lysenko \& Manko, 1988) бур'янів, визначено їх видовий склад, проаналізовано частоту трапляння в кам'янистих садах (табл. 2).

Табл. 1. Характеристика дослідних ділянок

\begin{tabular}{|c|c|c|c|c|}
\hline № 3/ח & Місце розміщення об'єкта & Категорія & Площа, $\mathrm{m}^{2}$ & Рельєф \\
\hline \multicolumn{5}{|c|}{ Національний ботанічний сад ім. М. М. Гришка НАН України (вул. Тимірязєвська, 1) } \\
\hline 1 & Ділянка № 1. "Гірський сад" & НЗК & 15000 & 2 \\
\hline 2 & Ділянка № 2. "Японський сад" & H3K & 10000 & 2 \\
\hline 3 & Ділянка № 3. "Гравійний сад" & HЗК & 1500 & 2 \\
\hline 4 & Ділянка № 4. "Австрійський альпійський сад" & H3К & 10000 & 2 \\
\hline 5 & Ботанічний сад ім. акад. О. Ф. Фоміна (вул. С. Петлюри, 1) & H3K & 10000 & 2 \\
\hline 6 & Парк "Перемога" (вул. Генерала Жмаченка) & HЗК & 2100 & 3 \\
\hline 7 & Парк "Сад каменів" (вул. Оболонська Набережна, 1) & HЗК & 3500 & 1 \\
\hline 8 & Голосіївська площа & НСП & 72 & 3 \\
\hline 9 & Сквер ім. О. Гончара (вул. О. Гончара) & НСП & 126 & 1 \\
\hline 10 & вул. Мельникова, 51-Б & НСП & 77 & 1 \\
\hline 11 & просп. Визволителів, 3-А & НСП & 155 & 1 \\
\hline 12 & Парк "Наталка" (вул. Оболонська набережна, 9) & H3К & 60 & 1 \\
\hline 13 & вул. Бастіонна, 6 & HOK & 5 & 3 \\
\hline 14 & Харківська площа & НСП & 88 & 3 \\
\hline 15 & просп. М. Бажана, 3-Б & HЗК & 10 & 1 \\
\hline 16 & Парк "Воїнів Інтернаціоналістів" (вул. Архітектора Вербицького) & HЗК & 132 & 3 \\
\hline 17 & Парк "Позняки" (вул. М. Драгоманова) & HЗК & 288 & 1 \\
\hline 18 & Парк ім. О. С. Пушкіна (просп. Перемоги, 40) & НЗК & 315 & 3 \\
\hline 19 & Парк "Веселка" (вул. Ружинська) & HЗК & 79 & 3 \\
\hline 20 & Либідська площа & НСП & 510 & 3 \\
\hline
\end{tabular}

Примітка: а) НЗК - насадження загального призначення, НОК - насадження обмеженого користування, НСП - насадження спеціального призначення; б) за особливостями рельєфу дослідні ділянки поділяємо: 1) на рівному рельєфі, 2) на схилах, 3) на штучному рельєфі.

Табл. 2. Поширення бур'янів у кам'янистих садах Києва

\begin{tabular}{|c|c|c|c|c|}
\hline \multirow{2}{*}{ № 3/п } & \multicolumn{2}{|c|}{ Назва } & \multirow{2}{*}{ Кількість облікових ділянок, шт. } & \multirow{2}{*}{ Поширення, \% } \\
\hline & українська & латинська & & \\
\hline 1 & Берізка польова & Convolvulus arvensis L. & 9 & 45 \\
\hline 2 & Буркун лікарський & Melilotus officinalis (L.) Pall. & 2 & 10 \\
\hline 3 & Галінсога дрібноквіткова & Galinsoga parviflora Cav. & 4 & 20 \\
\hline 4 & Гірчиця польова & Sinapis arvensis L. & 5 & 25 \\
\hline 5 & Грицики звичайні & Capsella bursa-pastoris L. & 8 & 40 \\
\hline 6 & Жовтець повзучий & Ranunculus repens $\mathrm{L}$. & 3 & 15 \\
\hline 7 & Зірочник середній & Stellaria media (L.) Vill. & 6 & 30 \\
\hline 8 & Злинка канадська & Erigeron canadensis L. & 2 & 10 \\
\hline 9 & Кульбаба лікарська & Taraxacum officinale Wigg. & 5 & 25 \\
\hline 10 & Лобода біла & Chenopodium album L. & 12 & 60 \\
\hline 11 & Мишій зелений & Setaria viridis $\mathrm{L}$. & 8 & 40 \\
\hline 12 & Паслін чорний & Solanum nigrum L. & 3 & 15 \\
\hline 13 & Пирій повзучий & Elymus repens (L.) Gould. & 9 & 45 \\
\hline 14 & Підмаренник чіпкий & Galium aparine L. & 4 & 20 \\
\hline 15 & Подорожник великий & Plantago major L. & 5 & 25 \\
\hline 16 & Свинорий пальчастий & Cynodon dactylon (L.) Pers. & 5 & 25 \\
\hline 17 & Тонконіг однорічний & Poa annua L. & 4 & 20 \\
\hline 18 & Щавель кінський & Rumex confertus Willd. & 2 & 10 \\
\hline 19 & Щириця звичайна & Amaranthus retroflexus L. & 4 & 20 \\
\hline
\end{tabular}

Бур'яни у кам'янистих садах представлені 19 видами, які належать до 12 родин. Найчастіше на дослідних ділянках трапляються бур'яни із родини Poaceae та поодиноко із родин: Convolvulaceae, Fabaceae, Ranunculaceae, Caryophyllaceae, Solanaceae, Rubiaceae, Plantaginaceae, Polygonaceae. Найпоширеніші бур'яни: берізка польова, грицики звичайні, зірочник середній, лобода біла, мишій зелений, пирій повзучий. Інші види бур'янів трапляються рідше (рис. 1).

За тривалістю життя бур'яни класифікують на малорічні (однорічні та дворічні) та багаторічні. Життєвий цикл малорічних бур'янів триває від кількох тижнів до двох років. Малорічні бур'яни розмножуються насінням. Серед малорічних бур'янів виділяють чотири бі- ологічні групи: ярі (ефемери, ранні ярі, пізні ярі), зимуючі, озимі та дворічні. Багаторічні бур'яни протягом життя декілька раз утворюють насіння та живуть багато років. За способом вегетативного розмноження багаторічні бур'яни поділяють на п'ять біологічних груп: кореневищні, коренепаросткові, стрижнекореневі, гронокореневі, повзучі (сланкі).

За нашими спостереженнями, всі зазначені вище бур'яни є непаразитними (автотрофними) рослинами, які здатні самостійно створювати органічні речовини, засвоюючи мінеральні речовини із грунту та вуглекислоту із повітря (Kosolap, 2004). За тривалістю життя найчастіше в кам'янистих садах трапляються однорічні бур'яни (55\%), відповідно $10 \%$ - дворічні бур'яни та 
30 \% - багаторічні. До біологічної групи відносять такі типи бур'янів: коренепаросткові, справжні, ярі, зимуючі, кореневищні (табл. 3). 3'ясовано, що більшість бур'янів належить до класу Дводольні - 75 \%. Боротьбу із бур'янами на облікових ділянках здійснювали двома способами: механічним (прополювання вручну) та хімічним (гербіцидами).

Табл. 3. Еколого-біологічна характеристика бур'янів

\begin{tabular}{|c|c|c|c|c|c|}
\hline$№$ з/п & Назва & Характер живлення & Тривалість життя & Біологічна група & Ботанічний клас \\
\hline 1 & Берізка польова & Непаразитні & Багаторічні & Корене-паросткові & Дводольні \\
\hline 2 & Буркун лікарський & Непаразитні & Дворічні & Справжні & Дводольні \\
\hline 3 & Галінсога дрібноквіткова & Непаразитні & Однорічні & Ярі & Дводольні \\
\hline 4 & Гірчиця польова & Непаразитні & Однорічні & Ярі & Дводольні \\
\hline 5 & Грицики звичайні & Непаразитні & Однорічні & Зимуючі & Дводольні \\
\hline 6 & Жовтець повзучий & Непаразитні & Багаторічні & Ярі & Дводольні \\
\hline 7 & Зірочник середній & Непаразитні & Однорічні & Ярі & Дводольні \\
\hline 8 & Злинка канадська & Непаразитні & Однорічні & Зимуючі & Дводольні \\
\hline 9 & Кульбаба лікарська & Непаразитні & Дворічні & Справжні & Дводольні \\
\hline 10 & Лобода біла & Непаразитні & Однорічні & Ярі & Дводольні \\
\hline 11 & Мишій зелений & Непаразитні & Однорічні & Ярі & Однодольні \\
\hline 12 & Паслін чорний & Непаразитні & Однорічні & Ярі & Дводольні \\
\hline 13 & Пирій повзучий & Непаразитні & Багаторічні & Кореневищні & Однодольні \\
\hline 14 & Підмаренник чіпкий & Непаразитні & Однорічні & Зимуючі & Дводольні \\
\hline 15 & Подорожник великий & Непаразитні & Багаторічні & Ярі & Дводольні \\
\hline 16 & Свинорий пальчастий & Непаразитні & Багаторічні & Кореневищні & Однодольні \\
\hline 17 & Тонконіг однорічний & Непаразитні & Однорічні & Зимуючі & Однодольні \\
\hline 18 & Щавель кінський & Непаразитні & Багаторічні & Стрижне-кореневі & Дводольні \\
\hline 19 & Щириця звичайна & Непаразитні & Однорічні & Ярі & Дводольні \\
\hline
\end{tabular}

Гербіциди (від лат. herba - трава і caedo - вбиваю) клас пестицидів, призначений для контролю небажаної рослинності. Їх використовують як для знищення вже вегетуючих рослин, так і для запобігання їх появи. Використання гербіцидів дає змогу максимально зменшити або ж повністю відмовитись від ручної праці або механічного обробітку грунту, що запобігає прояву грунтової ерозії та зменшує втрату вологи (Kataloh, 2005).

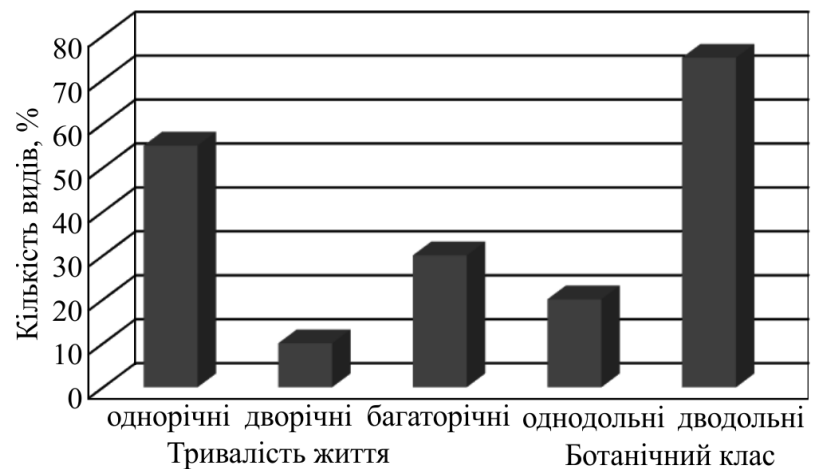

Рис. 1. Характеристика бур'янів

Однорічні бур'яни легко видалити за допомогою вузького совка. Бур'яни, які мають потужну кореневу систему, потрібно видаляти дуже ретельно, не залишаючи кореневища, які можуть дати початок новій рослині. Проаналізувавши найпоширеніші бур'яни, які трапляються у кам'янистих садах Києва (Dovidnyk burianiv, 2014; Dobrochaeva et al., 1999), запропоновано ефективні препарати для боротьби з ними компанії "Syngenta" (табл. 4).

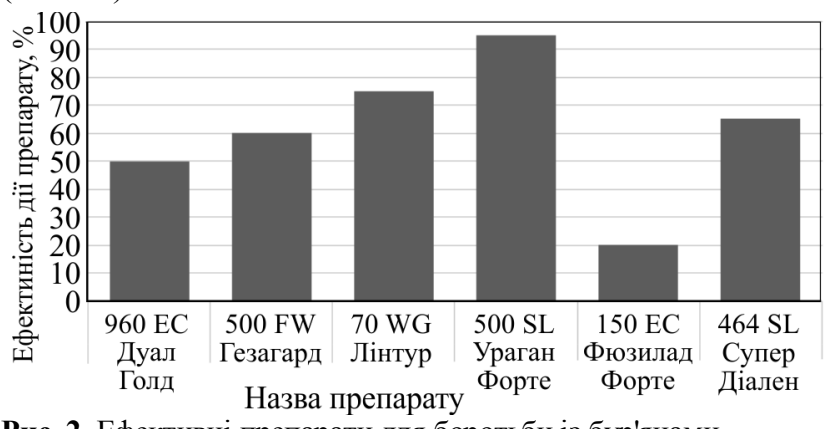

Рис. 2. Ефективні препарати для боротьби із бур'янами
Провівши детальне обстеження дослідних ділянок після застосування препаратів, можна стверджувати, що найкращу дію показав Ураган Форте 500 SL (неселективний післясходовий гербіцид системної дії для знищення однорічних та багаторічних бур'янів) - $95 \%$ та Лінтур $70 \mathrm{WG}-75 \%$, а гірший результат - Фюзилад Форте 150 ЕС (вибірковий системний посходовий гербіцид для боротьби з багаторічними злаковими бур'янами в посівах культурних рослин), оскільки він діє на конкретний вид бур'янів - 20 \% (рис. 2).

Табл. 4. Ефективні препарати для боротьби з бур'янами

\begin{tabular}{|c|c|c|c|c|c|c|c|}
\hline \multirow[b]{2}{*}{$\begin{array}{l}\text { № } \\
3 / \Pi\end{array}$} & \multirow[b]{2}{*}{ Назва виду } & \multicolumn{6}{|c|}{ Спектр дії гербіцидів } \\
\hline & & 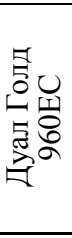 & 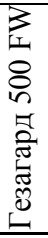 & 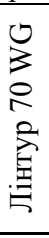 & 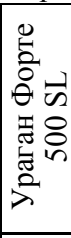 & 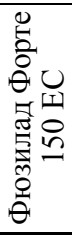 & 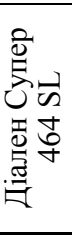 \\
\hline 1 & Берізка польова & - & - & + & + & - & + \\
\hline 2 & Буркун лікар & - & + & + & + & - & + \\
\hline 3 & $\begin{array}{l}\text { Галінсога дрібноквіт- } \\
\text { кова }\end{array}$ & + & + & + & + & - & + \\
\hline 4 & Гірчиця польова & + & + & + & + & - & + \\
\hline 5 & Грицики звичайні & + & + & + & + & - & + \\
\hline 6 & Жовтець повзучий & - & - & + & + & - & + \\
\hline 7 & Зірочник середній & + & + & + & + & - & + \\
\hline 8 & Злинка кан & - & + & + & + & - & - \\
\hline 9 & Кульбаба лікарська & - & - & + & + & - & + \\
\hline 10 & Лобода біла & + & + & + & + & - & + \\
\hline 11 & Мишій зелений & + & + & - & + & + & - \\
\hline 12 & Паслін чорний & + & + & + & + & - & + \\
\hline 13 & Пирій повзучий & - & - & - & + & + & - \\
\hline 14 & Підмаренник чіпкий & - & - & + & + & - & + \\
\hline 15 & Подорожник великий & + & + & + & + & - & + \\
\hline 16 & Свинорий пальчастий & - & - & - & + & + & - \\
\hline 17 & Тонконіг однорічний & + & + & - & + & + & - \\
\hline 18 & Щавель кінський & - & - & + & + & - & - \\
\hline 19 & Щириця звичайна & + & + & + & + & - & + \\
\hline
\end{tabular}

Примітка: дія препарату: + - діє - - не діє

Оброблення гербіцидами в кам'янистих садах проводили під час активного росту бур'янів за сприятливих погодних умов (відсутність поривчастого вітру, температура повітря не вище $+25^{\circ} \mathrm{C}$, відсутність роси), коли однорічні бур'яни мали 2-4 листки, а багаторічні досяг- 
ли висоти 10-12 см. Обприскування краще здійснювати вранці (до 10-11 год) або ввечері (18-22 год). Обприскування виконували свіжоприготовленим розчином у безвітряну погоду на ретельно підготовленому грунті. Максимальна кратність оброблення гербіцидами за сезон становила 1-2 рази залежно від виду препарату та інтенсивності росту бур'янів. Тривалість захисної дії триває 35-45 днів залежно від погодних умов.

Висновки. Для виявлення та обліку найпоширеніших бур'янів у кам'янистих садах проаналізовано 20 дослідних ділянок, які розміщені в насадженнях різного функціонального призначення. Виявлено, що найчастіше кам'янисті сади трапляються у насадженнях загального користування - 65 \%, в насадженнях спеціального призначення - $30 \%$ і тільки $5 \%$ належить до насаджень обмеженого користування. Встановлено, що догляд за кам'янистими садами здійснюють нерегулярно, тому трапляється багато бур'янів. Вивчено 19 видів бур'янів, які належать до класу Однодольні та Дводольні. Запропоновано найефективніші препарати компанії "Syngenta" для боротьби із синатропною рослинністю.
Результати досліджень вказують на найкращий препарат Ураган Форте 500 SL, спектр дії якого виявлено у $95 \%$.

\section{Перелік використаних джерел}

Barbarych, A. I., Visiulina, O. D., Vorobiov, M. Ye., Dobrochaieva, D. M., Dubova, O. M., et al. (1970). Buriany Ukrainy. [Weeds of Ukraine]. Kyiv: Scientific thought, 508 p. [In Ukrainian].

Dobrochaeva, D. N., Kotov, M. I., Prokudin, Yu. N., et al. (1999). Opredelitel vysshikh rastenii Ukrainy. [The determinant of higher plants of Ukraine], (2nd ed.). Kyiv: Fitosotciotcentr, 548 p. [In Russian].

Dovidnyk burianiv. (2014). Directory of weeds. URL: https://agroscience.com.ua/views/herba. [In Ukrainian].

Kataloh. (2005). Kataloh zasobiv zakhystu roslyn kompanii "SYNGENTA". [Catalog of plant protection products of the company "SYNGENTA"]. Kyiv, 116 p. [In Ukrainian].

Kosolap, M. P. (2004). Herbolohiia. [Herbology]. Kyiv: Aristei, 364 p. [In Ukrainian].

Veselovskyi, I. V., Lysenko, A. K., \& Manko, Yu. P. (1988). Atlas vyznachnyk burianiv. [Atlas is the key to weeds]. Kyiv: Urozhai, 72 p. [In Ukrainian].

С. Б. Ковалевский 1 Р. Я. Татарчук ${ }^{2}$

${ }^{1}$ Национальный университет биоресурсов и природопользования Украины, г. Киев, Украина 2 ОП НУБиП Украины "Боярский колледж экологии и природных ресурсов", г. Боярка, Украина

\section{СИНАНТРОПНАЯ РАСТИТЕЛЬНОСТЬ В КАМЕНИСТЫХ САДАХ КИЕВА}

Определена главная проблема ухода за каменистыми садами - борьба с сорняками. Обнаружена синатропная растительность (сорняки) каменистых садов Киева. Приведен перечень сорняков, которые чаще всего встречаются на опытных участках. Исследования проведены в насаждениях различного функционального назначения (насаждения общего пользования, насаждения ограниченного пользования, насаждения специального назначения). Проанализированы 19 видов сорняков, которые относятся к 12 семействам, учтены способы их распространения и причины устойчивости в каменистых садах. Установлено, что распространение сорняков очень истощают почву, затрудняют уход за каменистым садом, снижают общую декоративность каменистых композиций, способствуют развитию вредителей и болезней. Предложены методы борьбы с сорняками и ряд других агротехнических мероприятий, которые улучшат декоративный вид каменистых садов. Выделены биологические группы малолетних и многолетних сорняков. Обнаружено, что по продолжительности жизни в насаждениях преобладают однолетние сорняки, которые относятся к классу Двудольные. Проанализирован спектр действия гербицидов и определены наиболее эффективные препараты для борьбы с сорняками. В зависимости от вида препарата и интенсивности роста сорняков в каменистых садах предложена кратность обработки гербицидами. Исследования за ростом сорняков проведены с ранней весны до поздней осени. Работа выполнена путем маршрутных обследований.

Ключевые слова: сорняки; каменистый сад; уход; гербициды.

S. B. Kovalevskii ${ }^{1}$, R. Ya. Tatarchuk ${ }^{2}$

${ }^{I}$ National University of Life and Environmental Sciences of Ukraine, Kyiv, Ukraine ${ }^{2}$ Separated subdivision of NULES of Ukraine "Boyarka College of Ecology and Natural Resources", Boyarka, Ukraine

\section{SINANTROPIC VEGETATION IN STONY GARDENS OF KIEV}

In areas of stone gardens weeds get in different ways, namely, carried by the wind, birds and animals, together with the soil when creating these compositions. Therefore, weed control must be systematic, annual from early spring to late autumn, and the weeds shouldn't be allowed to bloom and ripen their seeds. To study the most common weeds in stone gardens, 20 experimental plots were analyzed in stands of various functional purposes. Experimental plots are characterized by different ground conditions, relief features (on flat relief, on slopes, on artificial terrain), size (small, medium, large), features of the composite solution (domination of vegetation over stones, dominance of stones over vegetation, dominance of the reservoir) and the presence of maintenance. Studies have shown that maintenance of stone gardens is not regular, and in some cases completely absent. Its main problem is the control of weeds, wild annuals and perennials, which have active growth, reproduction and adaptability to environmental conditions. Weeds in stone gardens are represented by 19 species, which belong to 12 families. In the experimental plots, weeds occur mostly often representing the family Poaceae and singly such families as Convolvulaceae, Fabaceae, Ranunculaceae, Caryophyllaceae, Solanaceae, Rubiaceae, Plantaginaceae, and Polygonaceae. According to our observations, all the above-mentioned weeds are non-parasitic (autotrophic) plants that are capable of creating organic substances independently, digesting mineral substances from the soil and carbon dioxide from the air. In terms of life expectancy, annual weeds (55\%) are most common in stone gardens, respectively $10 \%$ are biennial weeds and $30 \%$ are perennial. Having studied the species composition of the most common weeds in stone gardens, we proposed effective preparations for weed control of the company Syngenta Company. The maximum multiplicity of herbicide treatments per season was 1-2 times, depending on the type of preparation and the intensity of weed growth.

Keywords: weeds; stone garden; care; herbicides. 